\title{
Constructing the Localization of Marxism in Teaching
}

\author{
Chufang $\mathrm{Hu}^{*}$ \\ Yichun University, Yichun City 336000, Jiangxi Province, China. E-mail: hqsdfys@163.com
}

\begin{abstract}
The production of any kind of theory has its special and specific environment. Therefore, although truth can be universally applicable, it also needs to be associated with specific time, specific events, and specific environments in the process of combining it with practice, so that the truth can fully spread its wisdom, guide real life, and guide human society to develop scientifically and orderly. Based on the premise of fully understanding Marxism, this paper explores the localization of constructing Marxism in teaching based on the state of China. It proposes that it is necessary to fully integrate China's actual national conditions and realize the localization of Marxism in teaching from Chinese modernization, popularization, etc. in the new era, so as to fully integrate Marxism in China's new era of socialist construction, so that the Chinese people can get a sense of happiness in the localization of Marxism beliefs.
\end{abstract}

Keywords: Localization; Marxism Belief; Sinicization; Modernization; Popularization

\section{Introduction}

In 1938, the founding leader, Chairman Mao Zedong put forward the proposition of Sinicizing Marxism. Since then, the combination of Marxism and the actual development of China has always been regarded as the highest realm pursued by the Communist Party of China in ideology and theory. After the Fourth Plenary Session of the 17th CPC Central Committee, the localization of Marxism in teaching has aroused great attention from the entire party and the people across the country. However, China's specific national conditions are constantly changing. How to combine Marxism beliefs with China's specific condition, and localizing Marxism in teaching have become widespread concern in today's Chinese society.

\section{Connotation of localization of Marxism}

In fact, the localization of Marxism in teaching is the sinicization, modernization and popularization of Marxism by certain teaching measures. In other words, the localization of Marxist in teaching refers to the three aspects that require close attention when integrating Marxism with China's actual national conditions. First of all, the sinicization of Marxism in teaching means that Marxism in teaching should be combined with the specific conditions in China to generate new ideas and theories, which can guide the continued development of societies. Secondly, Marxism in teaching should be fully integrated with the characteristics and trends of contemporary China's condition. Thoughts should be innovated under the requirements of the times to fully meet the needs and development trends of contemporary China and be combined with the spirit of contemporary China. Only then can it play a positive role in the changes of the times. Finally, Marxism in teaching means that the teaching of Marxism should be remodeled in terms of speech or expression, so that the Chinese people can more easily understand the connotation and truth in it. The localiz- 
ation of Marxism in teaching fully reflects the combination of Marxist theory and practice, which has played a great role in the promotion of China's overall national strength. At the same time, it also provided a positive reference for the application of Marxism in other countries and regions.

\section{The role of constructing localization of Marxism in teaching}

Through practice, it has been found that the constructing localization of Marxism in teaching has mainly played the roles from the following aspects. First, it can combine Marxism with the actual condition in China and fully apply the basic concepts of Marxism to the development of China, which has further enriched China's ideological connotation. Second, it has promoted the further enrichment of Chinese core values. From the perspective of current social development, it is necessary for Chinese core values to be integrated with the basic theory of Marxism, so that the ideology of China can be advanced and scientific, and can gradually play an active role in the world.

\section{Exploration of constructing localization of Marxism in teaching}

\subsection{The teaching of Marxism and the condition of China are interrelated}

It was Chairman Mao who first proposed the idea to sinicize Marxism. Chairman Mao was a loyal Marxist. However, when he applied Marxism, he didn't copy it directly, but fully applied it to the specific conditions of Chinese society. For example, at that time China was in the stage of the revolution in full swing, Chairman Mao formulated new ideologies and theories by combining Marxist theory with the actual condition of Chinese society, pioneering the strategy and tactics of starting from rural areas, putting forward the unique idea for establishing military base, and establishing the united front. Historical practice proves that Chairman Mao's sinicization of Marxism, and the new ideas and theories that emerged from it, indeed guided the Chinese revolution correctly.

Nowadays, the localization and sinicization of Marxism in teaching in China is still continuing. Among them, the most notable is the formation and application of President Xi Jinping's important ideas. Through analysis of these important thoughts, it can be found that they are actually a full practice of Marxism. Marxism reveals the basic contradictions of the capitalist and points out the structural contradictions exposed by the financial crisis. President Xi Jinping makes full use of the objective laws dictated by Marxism, combines them with the current basic national conditions of China, forming a very strong contrast with capitalist structural contradictions, which fully demonstrates that the main idea of President Xi Jinping has a broader perspective on Marxist theories.

At the same time, President Xi Jinping's thoughts on governing the country are a comprehensive exploration of conforming to the Chinese social system under the premise of combining Marxism. President Xi once pointed out objectively that the current Chinese society has exceeded the imagination of early classic Marxist writers in terms of breadth and depth. Therefore, under such great changes, Marxist theories must go through further sinicization, modernization and popularization. To this end, President Xi Jinping combined with the specific content of Marxism to consolidate the status of Marxism in ideology, and ultimately cultivated and practiced the core values of socialism, so as to combine China's reform and opening up with the present globalization, multi-polarization, cultural diversification, and social informatization. On the basis of Marxism, the Chinese economy is undergoing structural adjustment and China's overall strength can be promoted.

In fact, as the largest socialist country in the world, all the leaders of People's Republic of China have insisted on localization of Marxism in teaching, and they all advocate the integration of the teaching of Marxism with China's specific national conditions. For example, Deng Xiaoping Theory, Three Represents of President Jiang Zemin and President Hu Jintao's important thoughts are the sinicization of Marxism. Marxism, as a great work of human thought, has been used flexibly by the Chinese people since it entered China in a practical and realistic manner. Practice has proved that the socialist China can only fundamentally solve the problems of development by sinicizing Marxism to embark on a uniquely socialist road with Chinese characteristics. 


\subsection{The teaching of Marxism is related to the reality of the times}

All ideologies and theories are marked with the characteristics of era. Marxism was born a hundred years ago. The German society and the world pattern a hundred years ago are completely different from today, so as the Chinese society. Therefore, for Marxism to guide the development of China, it must be modernized. From the perspective of China's development, it is not difficult to find that from Mao Zedong Thought to Deng Xiaoping Theory, and then to the "Three Represents" important thoughts and the Scientific Outlook on Development, all are the concrete manifestation of the modernized Marxism. When the Mao Zedong Thought was gradually generated, Chinese people were struggling for liberation, while Deng Xiaoping Theory and the Three Represents were formed when China entered the construction period. The proposal of the Scientific Outlook on Development highlights the change and development from the "development", which shows that Marxism is not immutable. Application of Marxism in the construction and development of China is not completely absorbing the original version, instead, it should be integrated with the contemporary characteristics of China, thus thinking about and solving the social problems facing in the current era, and giving Marxism a new content to promote the development of China's socialist.

For example, the development of China always relies on the development with unity. Marxism has repeatedly pointed out that it is a guide to action, a theory of development, and a practical application of general principles. It can be transferred according to the time and space. Therefore, during the modernization of Marxism, Chinese society has achievethe combination of development and persistence. In other words, Chinese people continue to adhere to the guiding position of Marxism teaching in the development of China. Instead of just memorizing and copying it completely, China accurately grasps the basic national conditions of the primary stage of socialism and the general trend of world economic development, pioneers and innovates. It is necessary to combine Marxism in teaching with China's economic reform and the development of China's current condition, and apply it to the construction of a new era of socialism to promote China's rapid and stable economic development.

In today's society, in order to pass on the domestic economic crisis, the United States began to act under the banner of de-globalization, and attempted to return to the Asia-Pacific area through its own military power, in order to further expand the control on Northeast Asia, and form a siege of China's economic development. Under such circumstances, through modernization of Marxism, President Xi Jinping proposed important thoughts with distinctive characteristics of the times. He has embarked on the economic development with "Belt and Road" initiative and vigorous development of the Silk Road and Maritime Silk Road. He leads China to strengthen full cooperation with other Asian, European, and African countries, forming an economic siege and anti-siege trend with the United States, guiding the steady and orderly development of China's economy. These are actually the concrete manifestations of the localization of Marxism in teaching. Therefore, the epoch-making of Marxism in teaching once again proved that the theory and the true meaning must stand the test of time and must combine with the times and reality. Only in this way can the theory be rejuvenated and upgraded.

\subsection{To combine the teaching of Marxism and the reality of popularization}

No matter how classic theories or refined thoughts are, they need a broad mass base of people to practice, so that they can fully prove their practical role. In fact, since the introduction of Marxism to China, there are still many people who regard Marxism as a very sophisticated subject. Although most Chinese people are very familiar with the name of Marxism, few of them have truly understood it. This shows that Marxism, as a doctrine that affects the lives of the people, needs further popularization, so that it can infiltrate and guide the lives of the general public.

Judging from the current combination of Marxism and China's development, Marxism is being widely translated, and more and more scholars have participated in the compilation of the complete works of Marx and Engels, adopting the fidelity rule that in line with Chinese expression and linguistic habits in the translation of their manuscripts. This allows more Chinese people to read and learn Marxism without too much difficult. At the same time, the localization of Marxism in teaching is also combined with contemporary new media, such as self-media APP, Weibo, and WeChat, to 
explain and post relevant theories, so that the public can make full use of fragmental time to learn and understand Marxism theories. When posting Marxist theories, the media has combined the theories with the public's interests, appeals, doubts, etc., and then made a popular explanation. It makes people think that Marxism is not belonging to minority, instead, it is actually closely related to people's daily life.

\section{Conclusion}

Marxism is the essence of human thought in the past 100 years. China is a typical socialist country in the world, whose localization of Marxism in teaching is actually the sinicization, modernization and popularization of Marxism, so that Marxism can continue to bloom with wisdom. More importantly, it can promote the comprehensive development of China's economy, politics, culture, science, education, etc., enhance China's overall national strength, and promote the great national rejuvenation. It can prove to the world that the socialist road that China has taken is based on the correct theory.

\section{References}

1. Zhang G. Promoting the study of the "three transformations" of Marxism: Thoughts after reading "The Chinese Communist Party's Classic Discourse Study on the Sinicization, Eraization, and Popularization of Marxism" (in Chinese). Ideological Education Guide 2014; (12): 134-136.

2. Wang X. On the "three transformations" of Marxism and the new discourse system of modern Marxism (in Chinese). Changjiang Forum 2014; (3): 3-7. doi: 10.3969/j.issn.1005-3980.2014.03.001.

3. Han Q, Chen Y. On the popularization of Marxism in China and the times (in Chinese). Marxism and Reality 2013; (3): 182-191. 